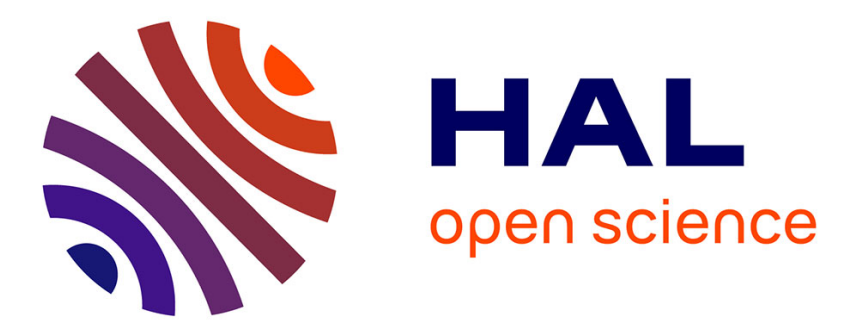

\title{
A model to evaluate the consequences of GM and non-GM segregation scenarios on GM crop placement in the landscape and cross-pollination risk management
} François Coléno, Frédérique Angevin, Baptiste Lécroart

\section{- To cite this version:}

François Coléno, Frédérique Angevin, Baptiste Lécroart. A model to evaluate the consequences of GM and non-GM segregation scenarios on GM crop placement in the landscape and cross-pollination risk management. Agricultural Systems, 2009, 101 (1-2), pp.49-56. 10.1016/j.agsy.2009.03.002 . hal00410394

\author{
HAL Id: hal-00410394 \\ https://hal.science/hal-00410394
}

Submitted on 20 Aug 2009

HAL is a multi-disciplinary open access archive for the deposit and dissemination of scientific research documents, whether they are published or not. The documents may come from teaching and research institutions in France or abroad, or from public or private research centers.
L'archive ouverte pluridisciplinaire HAL, est destinée au dépôt et à la diffusion de documents scientifiques de niveau recherche, publiés ou non, émanant des établissements d'enseignement et de recherche français ou étrangers, des laboratoires publics ou privés. 


\section{A model to evaluate the consequences of $\mathrm{GM}$ and non-GM segregation scenarios on GM crop placement in the landscape and cross-pollination risk management}

4 F.C. Coléno ${ }^{1}$, F. Angevin ${ }^{2}$, B. Lécroart ${ }^{2}$

1:INRA, UMR1048 SADAPT, F-78850 Thiverval Grignon, France

2 : INRA, UAR1240 Eco-innov, F-78850 Thiverval Grignon, France

* Corresponding author: F. C. Coléno, tel: +33-(0)1 30815931 fax: +33-(0)1 308159 39; e-mail: coleno@grignon.inra.fr

\section{Abstract}

Under European regulations, a product is labelled as GM (genetically modified) if more than $0.9 \%$ of one of its ingredients originates from GM material. During collection, crops from many fields are combined to fill a silo. To avoid the risk of mixing GM and non-GM harvests, it is possible to dedicate a silo to a given crop or to define specific times for GM and non-GM product delivery to silos. To evaluate these scenarios for the maize supply chain, we propose a combination of a model of farmers' varietal choice (based on profit evaluation at the field level, taking into account transport costs as well as price and cost differences between GM and non-GM products) and a spatially-explicit gene flow model. Consequences of different segregation strategies for collection zone organisation can therefore be compared while using the percentage of GM grain in non-GM crops due to cross-pollination. The 'temporal' strategy leads to a uniform area of GM or non-GM maize, depending on the prices and the weather risks. The 'spatial' strategy leads to areas of either GM or non-GM crops surrounding the corresponding collection silos. GM presence in non-GM batches depends on the size of the non-GM zone and on the prevailing wind. We show how divergent commercial strategies of grain merchants could have consequences on GM presence in non-GM batches. Keywords: GMO, co-existence, decision model, landscape, farming system

\section{Introduction}

The introduction of GM crops into Europe generated conflict between proponents and opponents of this technology (Levidow et al., 2000). Moreover, as a majority of European consumers is reluctant to eat GM foods (Eurobarometer, 2006), there is a demand for more stringent purity thresholds than those currently operating in existing crops grown in isolation, 
such as waxy maize or high erucic rapeseed. To satisfy this demand, while allowing farmers to make a practical choice between conventional, organic, and GM crop production, the European Commission has proposed several recommendations for ensuring coexistence at the field scale (EC, 2003a) and promulgated regulations controlling segregation of GM and nonGM products "from farm to fork" (EC, 2003b and c).

Within the food-processing industry, traceability of GM products has to be implemented throughout the whole supply chain. Indeed, positive labelling is compulsory when a product contains more than $0.9 \%$ of GM material per ingredient (EC, 2003c). In order to avoid such a positive labelling, PCR tests (Lüthy, 1999) can be used to assess the presence of GM material when DNA is present in the product. Moreover, the food industry uses risk management methods to identify critical points and to propose quality control methods such as the Hazard Analysis Critical Control Point (HACCP) method (Scipioni et al., 2005). As a consequence of potential cumulative risks in the food chain and to guarantee a level lower than $0.9 \%$ of GM material in non-GM products, a $0.1 \%$ maximum level of GM presence is required by the industry for non-GM batches delivered by farmers and grain merchants (Raveneau, 2005).

In this paper, we consider the consequences of the introduction of $\mathrm{Bt}$ maize (resistant to corn stalk borer) into European cropping systems. Indeed, Bt maize is the only GM crop grown commercially in the EU, mainly in Spain, where 60,000 hectares of it were grown in 2006 (James, 2006).

In the field, adventitious presence of GM material can have several sources: pollen flow, impurities in seed lots, and volunteer plants (Colbach et al., 2001). Due to the cold winter climate as well as ploughing in the majority of cropping systems including maize, this latter source can be considered negligible (Angevin et al., 2008). According to European recommendations (EC, 2003a), a farmer using GM seed has to use technical measures to avoid adventitious presence in the neighbouring non-GM fields, such as ensuring isolation distances and flowering time-lags (Beckmann et al., 2006), whose efficiency in decreasing cross-pollination risk is known (Halsey et al., 2005).

At the farm scale, the use of the same agricultural machinery (such as a seed drill or harvester) for both GM and conventional production increases the risk of admixture (Jank et al., 2006; Messéan et al., 2006). For grain merchants, the problem is to ensure segregation of the two products in their supply chain and, as far as possible, to manage cross-pollination risk between GM and non-GM fields in their collecting area.

Several European studies on segregation made in collaboration with grain merchants resulted in the identification of two possible management strategies (Miraglia et al., 2004): 
- A 'temporal strategy' where the two products are separated by the timing of the collection period. In this case, each product is delivered to the collection silo nearest to the farm, but within a given period. It is therefore not necessary to manage product separation in collection silos. Besides, by concentrating the collection of a product over a short period of time it is possible to have a sufficient flow of material to be able to dedicate a drying line to this product and to fill one or more storage bins. The inconvenience of this strategy for the grain merchant is that farmers can choose to deliver to a more flexible competitor when they want to harvest. This leads to a loss of volume collected and thus a loss of market share.

- A 'spatial strategy' based on a geographic grouping decided before sowing. Each collection silo and accompanying dryer(s) receives only one type of product, thereby defining an independent supply chain for each product. The risk of mixing between GM and non-GM products is therefore controlled. Moreover, farmers are informed about this allocation before sowing, so they can choose their crop type taking into account the product accepted by the nearest collection silo and the cost of transportation to other collection silos. This strategy indirectly encourages farmers to choose a particular crop type, but it does not protect grain merchants from farmers that deliver to a competitor closer to their farm who would accept both products.

Both of these strategies have implications for the allocation of GM and non-GM varieties over the agricultural landscape. While the second allows a homogeneous zone of each cultivar around silos, the first lets farmers choose their varieties.

Such strategies have not been developed in Europe, and specifically in France, because of the small GM maize area sown (James et al., 2006). In this paper, we evaluate the efficiency of these strategies to minimize cross-pollination of non-GM by GM crops. Such an evaluation is necessary to elaborate co-existence scenarios at the scale of the collection zone. We used a modelling approach by combining a model of farmer's choice between GM and non-GM varieties for each field in a zone (Coléno, 2008a) with a spatially-explicit model of gene flow, MAPOD® (Angevin et al, 2008).

\section{Methods}

\subsection{The farmer's choice model}

The model used is based on maximisation of the farmer's profit at the field level (Coléno, 2008a). To calculate this profit, we took into account the yield $(\mathrm{Y})$; the product price $(\mathrm{P})$; a 
potential quality loss (L) which is an estimate of the decrease in product quality, when the farmer is compelled to delay harvesting because of collection firm constraints; the seed costs $\left(\mathrm{C}_{\mathrm{s}}\right)$; the pesticide costs $\left(\mathrm{C}_{\mathrm{p}}\right)$ linked to the nature of the $\mathrm{GM}$ variety; the transportation costs $\left(\mathrm{C}_{\mathrm{tr}}\right)$; and the distance of the field from the silo where the product is accepted $(\mathrm{d})$.

Thus, we have:

$$
\begin{aligned}
& \text { Profit }_{\mathrm{GM}}=\mathrm{Y}_{\mathrm{GM}}{ }^{*} \mathrm{P}_{\mathrm{GM}} * \mathrm{~L}_{\mathrm{GM}}-\mathrm{C}_{\mathrm{s}}-\mathrm{Ctr} * \mathrm{~d} \\
& \text { Profit }_{\mathrm{nonGM}}=\mathrm{Y}_{\text {nonGM }}{ }^{*} \mathrm{P}_{\mathrm{nonGM}} * \mathrm{~L}_{\mathrm{nonGM}}-\mathrm{C}_{\mathrm{s}}-\mathrm{C}_{\mathrm{p}}-\mathrm{C}_{\mathrm{tr}} * \mathrm{~d}
\end{aligned}
$$

In the case of spatial separation, $L$ is equal to 0 . Farmers can deliver their crop whenever they want to the silo dedicated to the appropriate crop.

\subsection{The MAPOD® model}

In the case of maize, gene flow is mainly due to intra-specific cross-pollination in crop and seed production fields. Indeed, under normal European conditions, because of the cold winter climate as well as ploughing in the majority of cropping systems including maize, volunteer plants from previous maize crops are rare and may be controlled easily by agricultural techniques.

MAPOD $®$ is a spatially-explicit model that estimates the percentage of varietal impurities due to cross-pollination in maize as well as changes in these percentages due to modifications in cropping techniques (Angevin et al., 2008). It consists of two modules.

The first module determines the flowering date for female flowers, expressed in degree-days, as a function of climate and sowing date (Durand, 1969; Derieux and Bonhomme, 1982, 1990). Most of the varieties currently used display protandry, which means that male flowering begins several days before female flowering. The duration (in days) of this time lag can be used to calculate the flowering time for male flowers. Drought stress and sowing density affect protandry. Modelling the dynamics of male and female flowering then makes it possible to estimate the amounts of pollen produced by GM and non-GM varieties and the number of receptive silks for non-GM maize varieties. Factors affecting the viability of pollen and the receptivity of silks are taken into account. The composition of the pollen cloud in the air around the plants is therefore known on a day-to-day basis for the entire flowering period. Pollen dispersal is simulated in the second module by a Normal Inverse Gaussian function (NIG; Klein et al., 2003). It is a function of distance from the emitter, and its parameters are the direction and mean speed of the wind during the course of flowering and the difference in height between the panicle from which the pollen is emitted and the receptive silks. The 
composition of the pollen cloud at a given site in a non-GM field is determined by the pollen

130 dispersal curves for all the plants in the neighbourhood, whether close by or further away.

131 Each day, the frequency of GM seeds is calculated as the ratio of the number of non-GM

132 ovules fertilised by GM pollen to the total number of ovules fertilised. These daily results are

133 pooled to provide the extent of GM impurities in the non-GM crop.

134 The input variables for MAPOD® include certain traits of the varieties and certain

135 agricultural practices for each maize field as well as climatic factors for the region studied

136 (Table 1). The output is the percentage of GM impurities in the non-GM harvest on the scale

137 of a field, a group of fields, or a collection area. This model has been used to carry out several

138 co-existence studies (Angevin et al., 2002; Messéan et al., 2006).

139 The preliminary evaluation of MAPOD® was carried out by comparing simulation results

140 with data from two French and one American gene flow field trials. MAPOD® was found to

141 provide good average predictive values (Angevin et al., 2008). An indirect evaluation was

142 also performed by simulating the French seed production rules with the model. These

143 simulation results are consistent with the rates of impurities measured in commercial seed

144 lots. The effect of sowing male sterile maize rows to diminish risks of cross-pollination,

145 which was empirically tested as efficient by seed growers, appears to be correctly simulated

146 (See Messéan et al., 2006, for details). Further evaluation of the overall predictive quality of

147 the model is on-going in the case of several real agricultural contexts of GM commercial

148 releases in Spain.

\section{2.3. Input data and work assumption}

150 The farmer's choice model was used on a $100 \mathrm{~km}^{2}$ area (Figure 1), assuming that a field 151 would be sown with GM maize if this were be more profitable than a non-GM variety. All the 152 agricultural area was sown with maize. Four silos are located in this area.

153 We simulated both separation strategies, assuming that one firm owns silos 1,2 and 3, and 154 another owns silo 4. For the spatial strategy, silo 3 is dedicated to non-GM harvests and the 155 competing firm would accept all products, whether GM or not, at the same price.

156 Table 2 shows the values used for the calculation of profit in the farmer's choice models. We 157 choose a 7\% difference in price between GM and non-GM products. This difference allows 158 there to be a partition between GM and non-GM production. Using a higher or a lower price 159 difference would lead to a homogeneous landscape. As shown in Figure 2, the effect of a 160 price difference is very large, and all farmers can change their choice quickly depending on 161 price changes (Coléno, 2008a). 
162 For the temporal strategy we tested two assumptions: in one case, the GM crop is collected

163 when maize quality is at its optimum $\left(\mathrm{L}_{\mathrm{GM}}=0\right)$, and in the other, we assumed that non-GM 164 production is collected when maize quality is optimal $\left(\mathrm{L}_{\mathrm{nonGM}}=0\right)$. The simulation was carried 165 out with a loss of quality causing a $10 \%$ fall in price, which is consistent with the actions of 166 grain merchants (Raveneau, 2005).

167 With this model, on the level of an agricultural landscape, we can show the type of variety 168 (GM or non-GM) chosen for every field. The field allocation obtained is one of the input 169 variables of the MAPOD® model (Table 1). To run simulations calculating cross-pollination 170 between fields we assume that non-GM seeds do not contain GM impurities, that GM and non-GM cultivars have similar morphological and phenological characteristics (a risky situation), and that crop management is the same for both cultivars. We tested three types of wind: a north wind, a west wind, and the wind distribution obtained from the meteorological station located at Colmar $\left(48^{\circ} 05^{\prime} \mathrm{N}^{\circ} 21^{\prime} \mathrm{E}\right)$, which is shown in Figure 3.

175 Finally, to properly evaluate the efficiency of the various collection strategies on GM 176 impurity rates in non-GM silos, we have simulated one more situation in which the farmers 177 freely choose the type of variety they will sow ('case with no collection strategy'). We represented this situation by a random allocation of both varieties in the agricultural landscape. We assumed a proportion of $60 \%$ of GM maize in the total cultivated area, which is equivalent to the GM proportion in the spatial strategy with one grain merchant, with the values of the variables defined above.

\section{Results}

\subsection{Case with no collection strategy}

184 The first line of Table 3 presents the weighted mean of GM impurity levels in non-GM 185 batches due to cross-pollination for ten random distributions of GM crops in the zone. In all 186 cases, the maize collection did not comply with the $0.9 \%$ legal threshold, so it would not have 187 been possible to sell this maize to the non-GM market.

188 In view of our working assumptions and the features of the landscape studied (a fairly 189 uniform field size), we can see that the GM and non-GM field arrangement has little influence 190 on the GM percentage in non-GM batches. This is shown by the small difference in the 191 percentage of GM caused by wind direction, as well as by the small standard deviations 192 between the distributions of GM and non-GM allocations. For a given wind, the variability in 193 the mean accidental GM presence in the non-GM batches is quite low. On the other hand, the 
proportion of the non-GM area that is not compliant with the $0.9 \%$ threshold varies between $62 \%$ and $77 \%$ among the 10 crop allocations to fields and the three wind distributions.

\subsection{Temporal strategy}

197 Figure 4 presents the distribution of GM and non-GM crops in the collection area when the

198 temporal strategy is implemented. In this case, GM batches are collected at the beginning of 199 the harvesting period, before the non-GM ones, in order to avoid admixture within silos and 200 dryers. We find a homogeneous distribution of the variety when this collection strategy is used. Farmers' incomes are linked to the probability that the optimal maize harvest date is the period of collection for his crop. This probability depends on the period of the collection period. If the GM maize collection period is shorter than the non-GM one, the income of farmers growing GM cultivars is lower. As a result, farmers could therefore choose to only sow non-GM varieties (Figure 4a). The opposite situation is shown in figure $4 \mathrm{~b}$.

\subsection{Spatial strategy with one grain merchant}

207 We have assumed in this case that there is only one grain merchant in the territory, owning silos 1, 2 and 3 (Figure 1). The distribution of GM and non-GM varieties obtained by using the farmer's choice model is presented in Figure 5. The non-GM crops surround silo 3, which is dedicated to them, while GM crops are located around silos 1 and 2. The size of the non-

211 GM area can be modified according to the price difference between GM and non-GM maize 212 paid by the grain merchant.

213 The second line of Table 3 shows the percentage of GM grain in the non-GM silo as affected 214 by wind direction. In each case, this percentage is relatively low and below the $0.9 \%$ 215 threshold. It is thus possible to sell the collected batches on the non-GM market. Besides, this 216 percentage depends on the wind distribution and is higher with a northerly wind. Indeed, in 217 this case, the wind is blowing from the GM maize area to the non-GM maize area, which is 218 the worst case. There are two main prevailing winds (north and south) in the Colmar region. 219 A south wind is the more favourable, because the non-GM fields are upwind. That is why the cross-pollination rate is lower and closer to $0.1 \%$ with the real wind distribution. Taking into account the most unfavourable wind direction may lead to an overestimate of the risk of GM

222 admixture due to pollen flow. Grain merchants should thus consider the real wind 223 distribution.

224 If we compare the first and second lines of Table 3, we notice a large decrease in GM grain 225 percentage in the non-GM silo. Therefore, the organization of production in the collection 
zone can reduce the cross-pollination risk not by using isolation distances between GM and non-GM fields but by indirectly creating field clusters such as those that exist for specific maize crops such as waxy maize (Meynard and Le Bail, 2001). In this case, the core of the non-GM zone is isolated from GM sources while harvests of 'frontier' fields containing GM impurities could be diluted by mixing in the silo, or they could be collected separately.

\subsection{Spatial strategy with two grain merchants}

In this case, two grain merchants share the harvest collection within the study zone. The first merchant owns silos 1, 2, and 3, and collects GM maize in silos 1 and 2 and non-GM maize in silo 3. The second owns silo 4 and has a different commercial policy. GM and non-GM harvests are collected in the same silo and the company pays the same price for both products. Figure 6 shows the distribution of GM and non-GM varieties in the agricultural landscape resulting from these two competing commercial policies. We see that the second firm's strategy leads to the creation of a GM zone around silo 4, inducing a decrease in the non-GM area to $30 \%$ of the total area grown.

The third line of Table 3 shows the percentage of GM adventitious presence in the non-GM silo simulated by MAPOD®. Although GM production has increased in the zone, the percentage of GM grain in the non-GM batches remains low on average and below $0.9 \%$. It is therefore possible to sell the collected crops to the non-GM market. If we compare the second and the third line of Table 3, we see that the GM percentage remains relatively low. It is thus possible to limit the proportion of GM in the non-GM silo by organising production in the zone, even if it contains a high proportion of GM maize.

However, if we compare the second and the third line of Table 3 we see that the amount of GM adventitious presence is three times as great in the case of a westerly prevailing wind blowing from the GM area (Figure 6). This percentage still complies with the $0.9 \%$ threshold. However, the presence of several competitors in the same zone with different commercial policies can lead to an increase in GM impurity rates in the non-GM silo. Due to the stringent requirements of the maize food chain (Raveneau, 2005), this could lead to the loss of potential outlets for this crop.

\subsection{Impact of farmers' behaviour on non-GM silo purity}

Table 4 shows the percentage of the non-GM area cultivated in GM necessary to contaminate the non-GM silo to an extent which would deny access to the non-GM market. It also shows that a very small area sown with GM in the non-GM zone (from 0.36 to $0.73 \%$ ) would result 
in exclusion from the non-GM market. To prevent such a situation, companies would have to

259 adopt several strategies, such as crop contracts with farmers and information management

260

261

262

263

264

265

266

267

268

269

270

271

272

273

274

275

276

277

278

279

280

281

282

283

284

285

286

287

288 about farmers' practices. Such a policy would increase the transaction costs associated with co-existence.

\section{Discussion}

\subsection{Limitations of the farmer's choice model}

The model of crop allocation that we have used in this study is based on the maximisation of profit for each field. It has two assumptions that warrant discussion.

The first is that the risk covered by the use of GM maize is uniform over the collection zone. In fact, the distribution of the agronomic risk due to the corn borer is not uniform throughout any area, so the farmer's choice between GM and non-GM maize should be linked to this constraint (Bourguet et al., 2005). The use of agronomic variables in the model of farmers' choices might put into perspective the results presented here, because they would apply to larger and more representative geographical zones of the whole collection region of a grain merchant. Taking into account these agronomic factors and a larger area would allow one to search for alternative collection strategies. A spatial strategy with different delivery periods for each product could be considered. It would then be possible to take into account different flowering times to avoid field-to-field cross-pollination (Halsey et al., 2005; Messéan et al., 2006).

The second is that the optimal period for maize harvesting can be relatively short. The probability of being able to harvest during this period is connected to the total duration of collection. Such an assumption must be put into perspective. It applies in northern Europe and in Alsace in particular (Raveneau, 2005). In southern Europe (southwest France or Spain), the climate is more favourable and the optimal period for maize harvesting lasts longer. It is therefore possible to consider temporal strategies of collection that have a lower collection cost (Coléno, 2008b). In this case, farmers would support cross-pollination risk management, possibly growing GM varieties so as to set up isolation distances or non-GM buffer zones around their fields to avoid the risks of cross-pollination (EC, 2003a).

\subsection{Effect of the strategies studied on GM crop planting}

Introduction of GM varieties on a landscape scale comes up against regulations based mainly on the use of isolation distances (Beckmann et al., 2006), whatever the characteristics of the 
agricultural landscape. In regions where fields are small and fragmented, GM maize can only be sown in a small number of fields (Devos et al., 2007). Furthermore, when fields are small, with scattered ownership, non-GM production can lead to prohibition of GM production on almost all the land because of a domino effect (Demont et al., 2008). But this domino effect could lead to an exclusion of organic farming in the landscape, because of a greater isolation distance between GM and organic fields. All this takes only account of farmers' choices at an individual level, and so leads to solution for co-existence at the field level. Taking into account grain merchants' strategies allows GM and non-GM co-existence to be considered at the landscape level. It is thus possible to take into account incentive mechanisms with farmers (contract or price setting) in order to organise GM and non-GM production at a higher level than that of the field. Hence it is possible to bypass the problem of isolation distances between GM and conventional fields by concentrating non-GM production in specific zones. Co-existence of both crops in the zone may then be possible.

\subsection{How should the boundaries of the collection zone be managed?}

The definition of homogeneous zones, such as are used for waxy maize production in certain regions (Meynard and Le Bail, 2001), raises the question of boundary management. Indeed, we calculated the adventitious presence of GM material for the whole non-GM maize area. This average percentage masks the disparities between fields in the core of the non-GM zone and those located near the boundaries. In the case of maize, the quantity of dispersed pollen diminishes with distance (Bateman, 1947a; b; Raynor et al., 1972). Non-GM fields in the border zone are closer to the GM pollenemitting source than those in the core, and consequently have a higher GM rate than the average (results not shown). The management of these fields thus requires:

- limiting the rate of cross-pollination by implementing co-existence measures such as isolation distances (Jones and Brookes, 1950), time-lag of flowering (Halsey et al., 2005), or non-GM buffer zones (Messéan et al., 2006);

- setting up compensation mechanisms for non-GM crops that would have to be sold as GM. Such mechanisms can be implemented either via producers' clubs (Furtan et al., 2007) or they may be provided by grain merchants in order to ensure a low GM rate in the core of the non-GM zone. 


\subsection{How to deal with grain merchants with divergent strategies?}

322 Use of appropriate collection strategies realise on the creation of a non-GM production zone of sufficient size to guarantee a low percentage of GM in non-GM batches. A decrease in the size of the non-GM zone, because of competitors with different commercial strategies, causes an increase in the GM percentage in non-GM batches. Consequently, the non-GM zone should be located in areas where the competition between grain merchants is low. Another possibility is that grain merchants coordinate GM and non-GM variety allocation in the zone. This leads to the development of co-opetition strategies (Nalebuff and Brandenburger, 2002) at the scale of the collection zone. Therefore, GM and non-GM crop co-existence could lead to new collective strategies of the various firms involved in the supply chain, between clients and suppliers as well as between competitors.

\section{Conclusion}

333 To overcome difficulties in the segregation of GM and non-GM crops in the supply chain, it is necessary to dedicate silos and dryers to either crop over the course of time or by defining GM and non-GM zones in the agricultural landscape and collection infrastructure.

These two basic solutions lead to an increase in collection costs due to an increase in transport costs and a decrease in the flexibility of the collection process (Bullock and Desquilbet, 2002; Coléno, 2008b). Moreover, these strategies do not have the same effect on landscape organization and on the risk of cross-pollination between GM and non-GM fields. The spatial strategy could allocate parts of the landscape to each crop and thus minimize accidental GM presence. The temporal strategy would lead to uniform GM and non-GM zones while only considering the farmer's economic benefit. In this case, there is no risk of cross-pollination. But, from an agronomic point of view in relation to the different exposures to risk concerning $\mathrm{Bt}$ maize, it is possible that the spatial allocation of GM and non-GM crops would no longer be homogeneous. In such a case, considering European regulations, GM production might have to be reduced because of the impossibility of producing a GM crop close to non-GM fields of the same species (Demont et al., 2008; Devos et al., 2007). Moreover, in order to go further to evaluate collection strategies at the landscape level it id necessary to improve the two models used there. Concerning the farmer's choice model, it would be possible to develop a multi-criterion model of farmer's choice that takes into

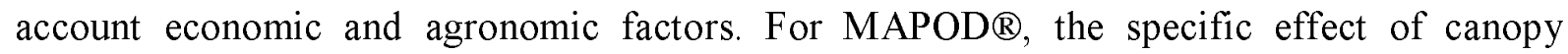

352 discontinuities (such as other crops, hedges or roads) on pollination patterns at field edges needs to be better modelled 
354 Considering the difficulties of segregation management, it seems necessary to consider 355 landscape governance (Byrne and Fromherz, 2003) in order to define an optimal collection strategy for grain merchants that takes into account the cost management of segregation in the supply chain as well as the costs of managing GM crop distribution in the agricultural landscape. Specifically, it seems necessary to evaluate the feasibility of cooperation between different grain merchant companies in order to manage the collection zone.

\section{Acknowledgments}

Original maps were provided by the Institute for the Protection and Security of the Citizen (Joint Research Centre of the European Union) and AUP-ONIGC - ex ONIC (Office National Interprofessionnel des Céréales). We thank Ms Tanis-Plant for editorial advice in english and K. Adamczyk for her technical help.

Funding for this research was provided by the French Ministry of Research through the national program "ACI OGM et environnement" and by the European commission through the Sixth Framework Program, integrated project Co-Extra (contract Food-2005-CT-007158).

\section{References}

Angevin, F., Colbach N., Meynard, J.M., Roturier, C., 2002. Analysis of necessary adjustements of farming practices, In A.-K. Bock, Lheureux, K., Libeau-Dulos, M., Nilsagard H., Rodriguez-Cerezo, E., eds. Scenarios for co-existence of genetically modified, conventional and organic crops in European agriculture. Technical Report Series of the Joint Research Center of the European Commission. EUR 20394 EN Angevin, F., Klein, E.K., Choimet, C., Gauffreteau, A., Lavigne, C., Messéan, A., Meynard, J.M., 2008. Modelling impacts of cropping systems and climate on maize cross-pollination in agricultural landscapes: The MAPOD model., European journal of Agronomy. 28, 471-484

Bateman, A. J., 1947a. Contamination in seed crops I: Insect pollination. J. Genet. 48, $257-$ 275 .

Bateman, A. J., 1947b. Contamination in seed crops II: wind pollination. Heredity. I, 235-246. Beckmann, V., Soregaroli, C., Wesseler, J., 2006. Coexistence rules and regulations in the European Union. American Journal of Agricultural Economics. 88, 1193-1199.

Betbesé, I., Lucas J.A., 2006. Varietats de panís, Dossier tècnic, Ruralcat. 24p

Bourguet, B., Desquilbet, M., Lemarié, S., 2005. Regulating insect resistance management: the case of non-Bt corn refuges in the US. Journal of Environmental Management. 76, 210220. 
386 Brookes, G., 2002. The farm level impact of using Bt maize in Spain. PGEecnomics, 23p.

387 http://www.pgeconomics.co.uk/pdf/bt_maize_in_spain.pdf

388 Bullock, D.S., Desquilbet, M., 2002. The economics of non-GMO segregation and identity 389 preservation. Food Policy 27, 81-99.

390 Byrne, P. F., Fromherz, S., 2003 Can GM and Non-GM Crops Coexist? Setting a Precedent in 391 Boulder County, Colorado, USA, Journal of Food, Agriculture \& Environment 1, 258-261.

392 Colbach, N., Clermont-Dauphin, C., Meynard, J. M., 2001. GENESYS: a model of the 393 influence of cropping system on gene escape from herbicide tolerant rapeseed crops to rape 394 volunteers. II. Genetic exchanges among volunteer and cropped populations in a small region. 395 Agric. Ecosyst. Environ. 83, 255-270.

396 Coléno, F.C., 2008a. A simulation model to evaluate the consequences of GM and non-GM 397 segregation rules on landscape organization. Journal of International Farm management. 4-3 398 (www.ifmaonline.org/pdf/journals/Vol4_Ed3_Coleno.pdf)

399 Coléno, F.C., 2008b. Simulation and evaluation of GM and non-GM segregation management 400 strategies among European grain merchants. Journal of Food Engineering. 88; 306-314

401 Comité National du Transport. 2006. Simulateur de prix de revient transport régionaux 402 (www.cnt.fr).

403 Demont, M., Daems, W., Dillen, K., Mathijs, E., Sausse, C., Tollens, E., 2008. Regulating 404 coexistence in Europe: Beware of the domino-effect!. Ecological Economics, 64, 683-689.

405 Derieux, M., Bonhomme, R. 1982. Heat unit requirements for maize hybrids in Europe. 406 Results of the European FAO sub-network. I. Sowing-silking period. Maydica. 27, 59-77.

407 Derieux, M., Bonhomme, R. 1990. Heat units requirements of maize inbred lines for pollen 408 shedding and silking: results of the European FAO network. Maydica. 35, 41-46.

409 Devos, Y., Reheul, D., Thas, O., De Clercq, E. M., Cougnon, M., Cordemans, K., 2007.

410 Implementing isolation perimeters around genetically modified maize fields. Agronomy For 411 Sustainable Development, 27, 155-165.

412 Durand, R. 1969. Signification et portée des sommes de températures. Bull. tech. inf. 238, 413 185-190.

414 Eurobarometer. 2006. Europeans and biotechnology in 2005: Patterns and trends. European 415 Commission's Directorate General for Research, Eurobarometer 64.3, 85 p.

416 European Commission. 2003a. Commission recommendations of 23 July 2003 on guidelines 417 for the development of national strategies and best practices to ensure the co-existence of 418 genetically modified crops with conventional and organic farming, 2003/556/EC (notified 
under document number $\mathrm{C}(2003)$ 2624), , pp. pp 36-47. Official Journal of the European 420 Union, 29/07/2003, vol. 46, L189.

421 European Commission. 2003b. Regulation (EC) $\mathrm{N}^{\circ} 1829$ / 2003 of the European Parliament and of the Council of 22 September 2003 on genetically food and feed, pp. pp1-23. Official Journal of the European Union, 18/10/2003, vol. 46, L268.

European Commission. 2003c. Regulation (EC) $N^{\circ} 1830 / 2003$ of the European Parliament and of the Council of 22 September 03 concerning the traceability and labelling of genetically modified organisms and the traceability of food and feed products produced from genetically modified organisms and amending Directive 2001/18/EC, pp. pp 24-28. Official Journal of the European Union, L268, 18/10/2003, vol. 46, L268.

Furtan, W.H., Güzel, A., Weseen, A.S., 2007. Landscape clubs: co-existence of genetically modified and organic crops. Canadian Journal of Agricultural Economics, 55, 185-195.

Halsey, M.E., Remund, K.M., Davis, C.A., Qualls, M., Eppard, P.J., Berberich, S.A., 2005. Isolation of maize from pollen-mediated gene flow by time and distance. Crop Science, 45, $2172-2185$.

James, C., 2006. Global Status of Commercialized Biotech/GM Crops: 2006. ISAAA Brief No. 35. ISAAA: Ithaca, NY.

Jank, B., Rath, J., Gaugitsch, H., 2006. Co-existence of agricultural production systems. Trends in Biotechnology, 24, 198-200.

Jones, J. M., Brooks, J. S., 1950. Effectiveness and distance of border rows in preventing outcrossing in corn. Oklahoma Agric. Exp. Sta. Tech. Bull.T-38: 1-18

Klein, E. K., Lavigne, C., Foueillassar, X., Gouyon, P. H., Laredo, C. 2003. Corn pollen dispersal: Quasi-mechanistic models and field experiments. Ecol. Mon. 73, 131-150.

Levidow, L., Carr, S., Wield, D., 2000. Gentically modified crops in the European Union: regulatory conflicts as precautionary opportunities. Journal of Risk Research 3, 189-208.

Lüthy, J., 1999. Detection strategies for food authenticity and genetically modified foods. Food control, 10, 259-361.

Messéan, A., Angevin, F., Gómez-Barbero, M., Menrad, K., Rodríguez-Cerezo, E., 2006. New case studies on the coexistence of GM and non-GM crops in European agriculture, Technical Report Series of the Joint Research Center of the European Commission, EUR $22102 \mathrm{En}, 112 \mathrm{p}$.

Meynard, J. M., Le Bail, M., 2001. Isolement des collectes et maîtrise des disséminations au champ, Rapport du groupe 3 du programme de recherche Pertinence économique et faisabilité d'une filière sans utilisation d'OGM. INRA - FNSEA, 56 p. 
453 Miraglia, M., Berdal, K.G., Brera, C., Corbisier, P., Holst-Jensen, A., Kok, E.J., Marvin, 454 H.J.P., Schimmel, H., Rentsch, J., Van Rie, J.P.P.F., Zagon, J., 2004. Detection and 455 traceability of genetically modified organisms in the food production chain. Food and 456 Chemical Toxicology. 42, 1157-1180.

457 Nalebuff, B.J., Brandenburger, A.M., 2002. "Co-opetition”. Proflebooks, London. 275p.

458 Raveneau, A., 2005. Stratégies de séparation des filières OGM et non OGM en amont de la 459 chaîne logistique d'approvisionnement. Mémoire de fin d'étude de l'ENESAD. 33p

460 Raynor, G. S., Ogden, E. C., Hayes, J. V. 1972. Dispersion and deposition of corn pollen from 461 experimental sources. Agron. J. 64, 420-427.

462 Scipioni, A., Saccarola, G., Arena, F., Alberto, S., 2005. Strategies to assure the absence of 463 GMO in food products application process in a confectionery firm. Food control 16, 569-578. 


\section{Figures}

465

466 Figure 1: Map of the region used for simulations (region of Selomes, Loir et cher department,

467 France). Silo locations are shown by circles. (Courtesy of the Institute for the Protection and Security of

468 the Citizen, Joint Research Centre of the European Union and AUP-ONIGC - ex ONIC, Office National

469 Interprofessionnel des céréales/French Interprofessional agency for cereal crops)

470 Figure 2: effect of price difference between GM and non-GM production on landscape use

471 with a $7.15 \%$ yield difference

472 Figure 3: Wind distribution at Colmar

473 Figure 4: Allocation of GM and non-GM varieties. Temporal strategy

474 (a) with GM harvest duration shorter than non-GM harvest duration, (b) with GM harvest 475 duration longer than non-GM harvest duration

476 Figure 5: Allocation of GM and non-GM varieties, spatial strategy with one grain merchant

477 Figure 6: Allocation of GM and non-GM varieties, spatial strategy with two grain merchants 


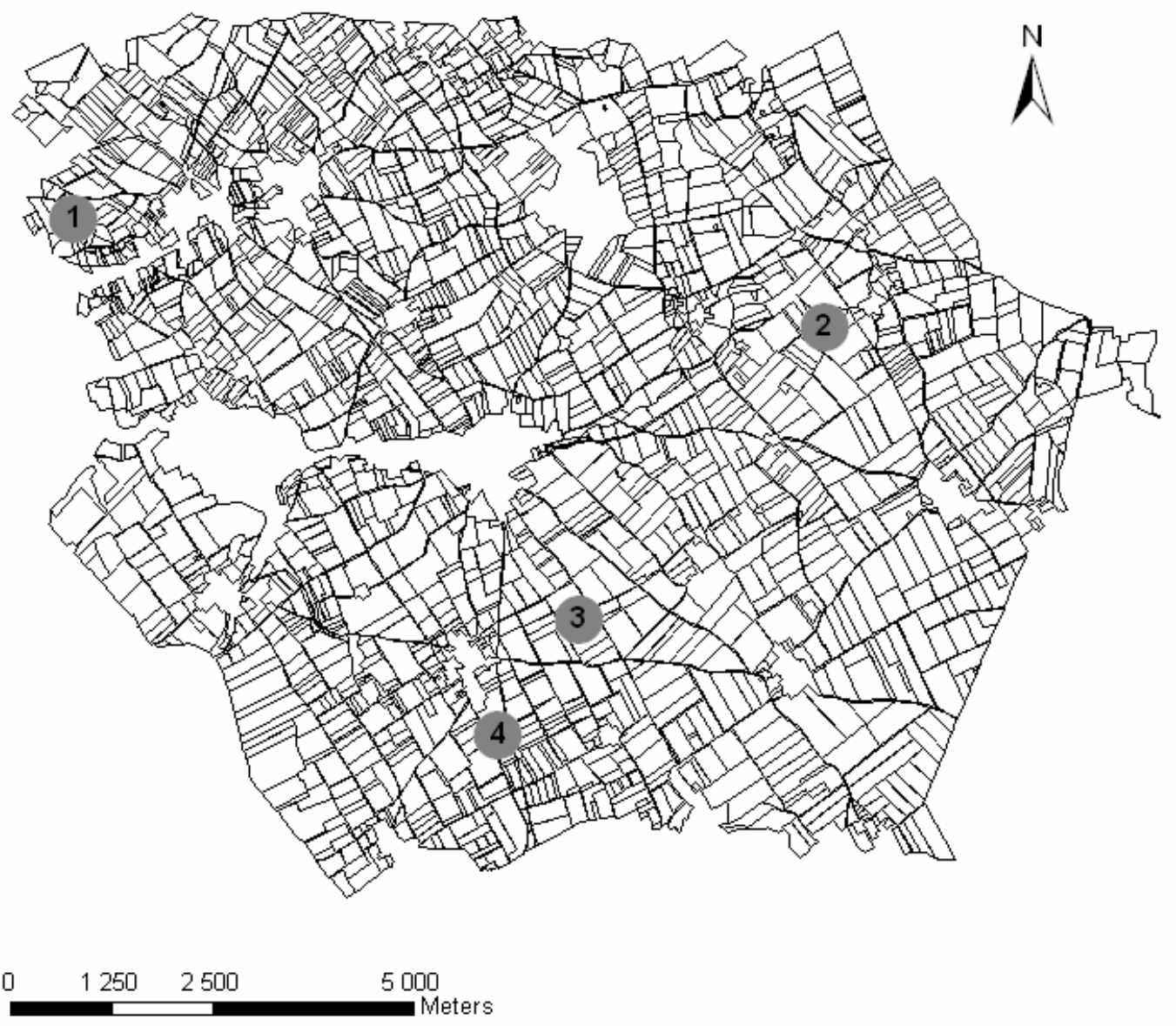

479

Figure 1 


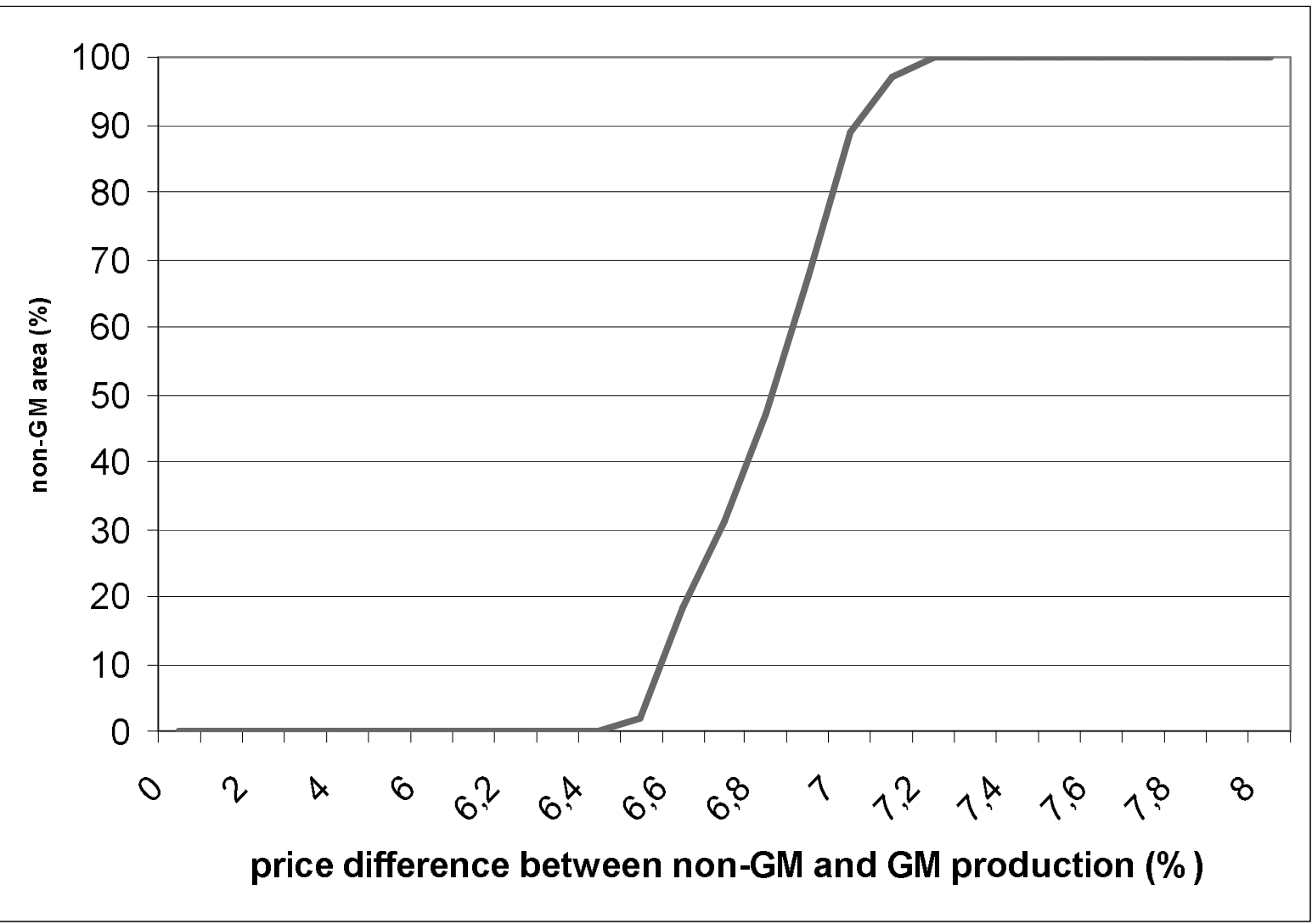

482

Figure 2 


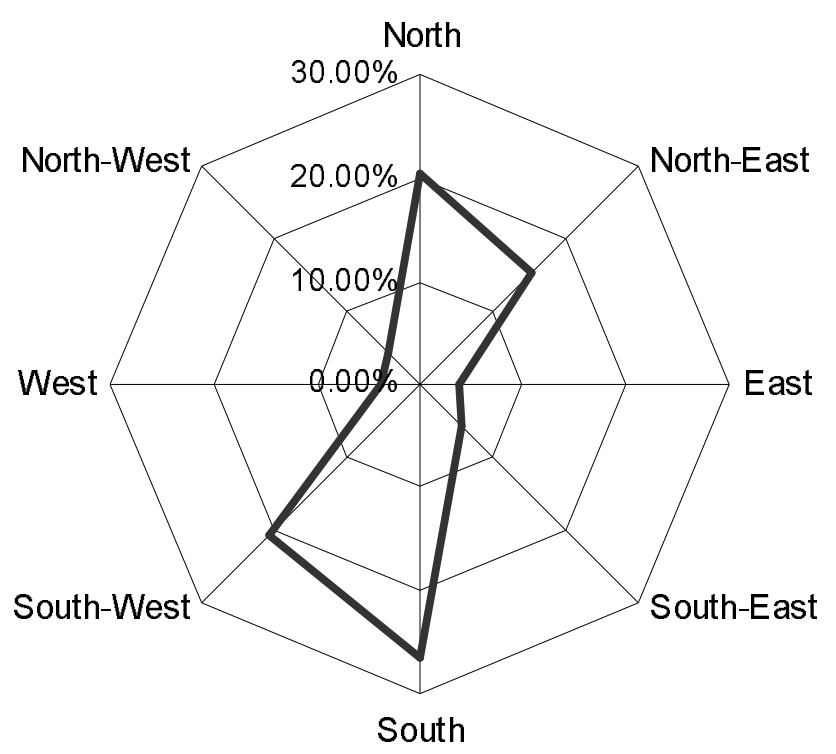

483

484

Figure 3 
485

486
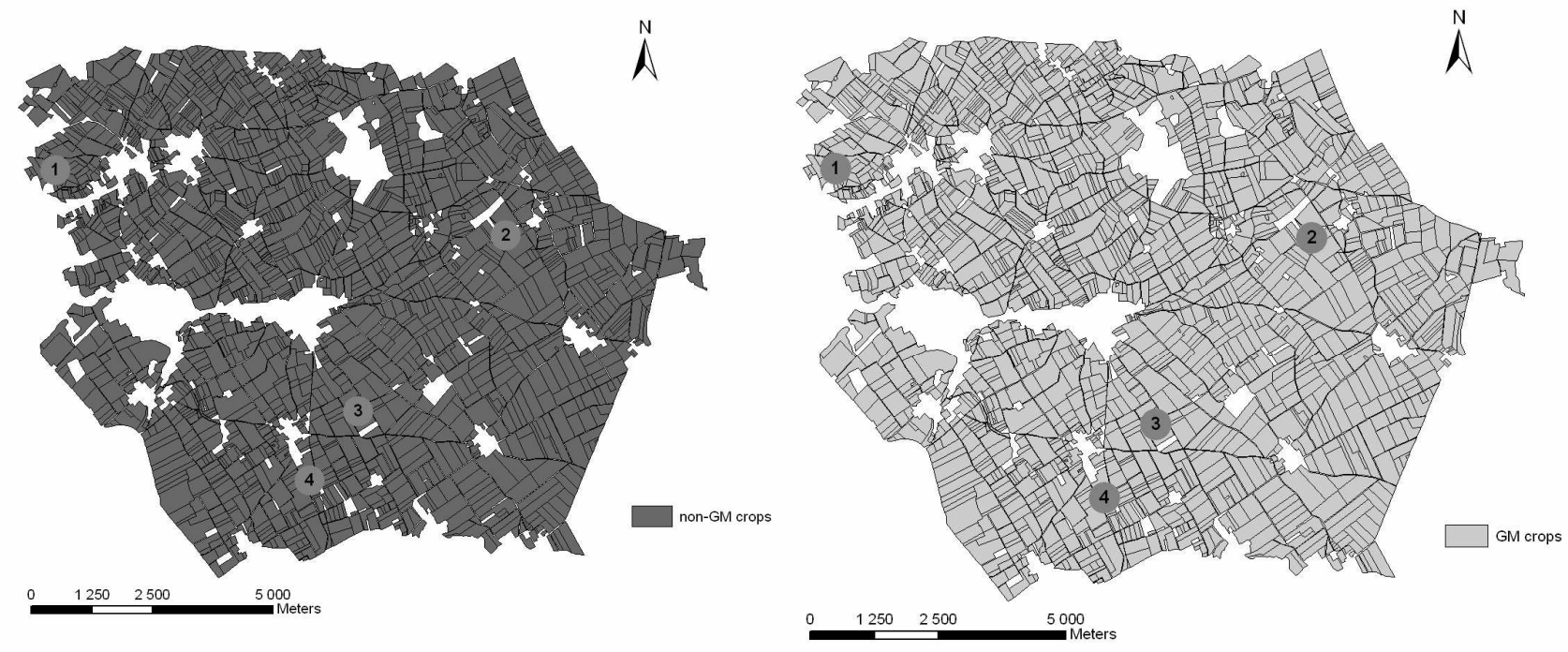

a

b

487

488

Figure 4 


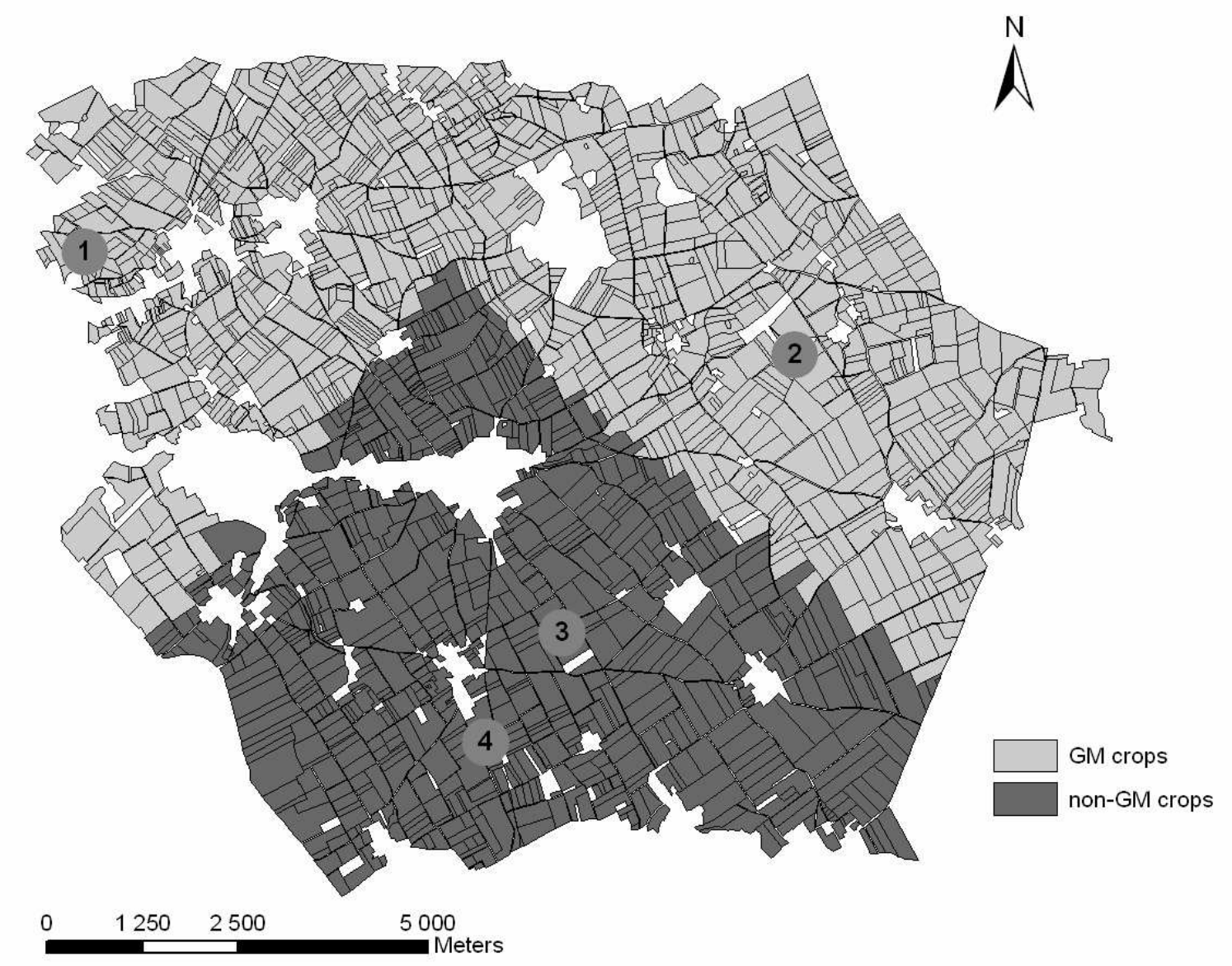

489

490

Figure 5 


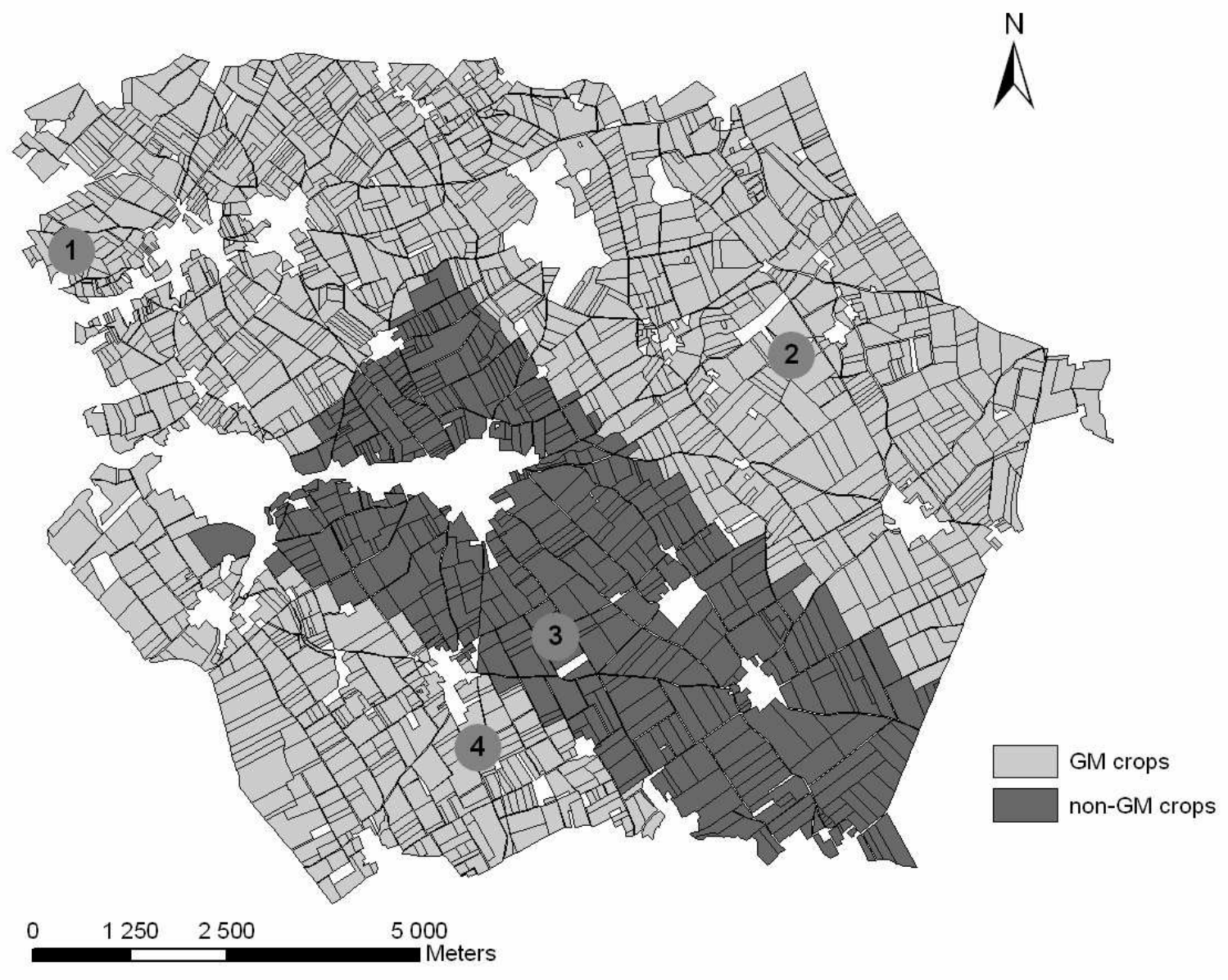

492

493

494

Figure 6 


\section{Tables}

496

497 Table 1: MAPOD® input data

498 Table 2: Work hypotheses

499 Table 3: GM impurity percentages in non-GM maize batches at the collection silo for the 500 different scenarios.

501 Table 4: percentage of the non-GM zone cultivated with GM that would lead to loss of the 502 non-GM market. 
Table 1

504

\begin{tabular}{ll}
\hline Input data & Description \\
\hline Field plan & Shape and size of fields, location of GM and non-GM maize crops \\
\hline Climate (per day) & Temperature; rain; wind speed and direction \\
\hline Cropping systems & $\begin{array}{c}\text { Sowing dates and densities, drought stress before flowering, drought } \\
\text { stress during flowering }\end{array}$ \\
\hline Variety & $\begin{array}{c}\text { Quantity of pollen per plant, pollen sensitivity to high temperature, } \\
\text { temperature needs between sowing and female flowering, } \\
\text { genotype of GM: homozygous or heterozygous } \\
\text { Tassel height of each variety, Ear height of non-GM variety }\end{array}$ \\
\hline
\end{tabular}


Table 2

\begin{tabular}{llll}
\hline & GM maize & Non-GM maize & Sources \\
\hline Seed price & $210 / 223 € /$ ha & $181 / 192 € /$ ha & Brookes, 2002 \\
\hline Treatment & 0 & $24 € /$ ha & Brookes, 2002 \\
\hline Yield & $100 \%$ & $93 \%$ & Betbesé and Lucas, 2006 \\
\hline Price & $100 € / \mathrm{t}$ & $107 € / \mathrm{t}$ & Coléno 2008a \\
\hline Loss of quality & $10 \%$ of the & $10 \%$ of the & Raveneau, 2005 \\
& price & price & \\
\hline Transport costs & $0.05 € / t / \mathrm{km}$ & $0.05 € / \mathrm{t} / \mathrm{km}$ & Comité National Routier, 2006 \\
\hline
\end{tabular}


Table 3

510

\begin{tabular}{lccc}
\hline Strategy & $\begin{array}{c}\text { Colmar wind } \\
\text { distribution }\end{array}$ & North wind & West wind \\
& $1.41(0.03)$ & $1.42(0.04)$ & $1.44(0.04)$ \\
$60 \%$ of GM randomly allocated & & & \\
$\begin{array}{l}\text { and standard deviation in bracket } \\
\text { "no collection strategy" }\end{array}$ & 0.16 & 0.25 & 0.18 \\
\hline $\begin{array}{l}\text { Spatial strategy with one grain } \\
\text { merchant }\end{array}$ & & & 0.54 \\
\hline $\begin{array}{l}\text { Spatial strategy with two grain } \\
\text { merchants }\end{array}$ & 0.54 & 0.27 & \\
\hline
\end{tabular}


Table 4

512

\begin{tabular}{lll}
\hline Strategy & $\begin{array}{l}\text { Colmar wind } \\
\text { distribution }\end{array}$ & North wind
\end{tabular}$\quad$ West wind

$\begin{array}{llll}\text { Spatial strategy with one grain } & 0.73 & 0.63 & 0.70\end{array}$
merchant

\begin{tabular}{llll}
\hline Spatial strategy with two grain & 0.36 & 0.61 & 0.36
\end{tabular}
merchants 